\title{
Agronomic characteristics and oil content of Brazilian sunflower hybrdids under different sowing densities
}

\author{
Martios Ecco* ${ }^{1}$, Fabio Duarte Carlos ${ }^{1}$, Paulo Ricardo Lima ${ }^{2}$, Alfredo Richart ${ }^{1}$, Gustavo Ferreira \\ Coelho $^{1}$, Augustinho Borsoi ${ }^{2}$
}

${ }^{1}$ Pontifical Catholic University of Paraná, PUCPR, Agronomy Course of the School of Life Sciences, Av. Da União 500, Jardim Coopagro, CEP 85902-532, Toledo, Paraná, Brazil

${ }^{2}$ Assis Gurgacz Faculty, FAG, course of agronomy, Av. Das Torres, 500 - FAG Allotment, CEP 85806-095, Cascavel, Paraná, Brazil

\section{*Corresponding author: ecco.martios@pucpr.br}

\begin{abstract}
The sunflower (Helianthus annuus L.) has good productive capacity and the increase in production is possible by using hybrids adapted to the sowing region and an adequate arrangement of plants without losing quality and oil content. The objective of this work was to evaluate two sunflower hybrids cultivated in different sowing densities, observing the influence on the agronomic characteristics and oil content of the cultivation. The experiment was conducted at the experimental field of the Pontifical Catholic University of Paraná, Toledo. The experimental design was randomized blocks in $2 \times 4$ factorial scheme, with four repetitions consisted of two plant genotypes (BRS324 and M734) and four plant densities (30, 40, 50 and 60 thousand ha-1 plants). The variables analyzed in the field were: plant height, stem diameter, number of leaves, chapter thickness and chapter size. On the other hand, the variables: mass of one thousand sunflower achene, yield and oil content were analyzed at PUCPR laboratory. According to the results obtained, there was interaction between the density of the BRS324 genotype with plant height, stem diameter and mass of a thousand sunflower achene. For the other variables there was a significant difference as a function of the genotype. The cultivar BRS324 produced a better oil content. For plant height and stem diameter, the cultivar showed opposite behavior, possibly due to adaptation in the western region of Paraná. The variable mass of one thousand sunflower achene was decreased due to the increase of the population density for cultivar BRS324.
\end{abstract}

Keywords: Genotype, Helianthus annuus, Oil.

Abbreviations: ha_hectare (Ten thousand square kilometers); mm_millimeter; S_south; W_west; m_meter; pH_hydrogen potential; SB_base sum; CEC_Cation exchange capacity; V_base saturation; MSD_ minimal significant difference.

\section{Introduction}

Sunflower (Helianthus annuus L.) is cultivated in all continents, as one of the vegetable species with the highest renewable energy potential and production of edible oil. It is an important income option in agricultural activity, succession and rotation in the grain producing regions, both in the summer and winter seasons (Silva et al., 2009). Sunflower can adapt to several environments, being able to tolerate low temperatures and water stress, with temperatures above $10{ }^{\circ} \mathrm{C}$ being more satisfactory (Santos and Zonetti, 2009). The requirements can vary from $200 \mathrm{~mm}$ to more than $900 \mathrm{~mm}$ per cycle, if well distributed. For being a rustic plant, it has an easy adaptation on different types of soil, but it has a preference for corrected, deep, fertile, flat and well drained soils (Castro et al., 1996). Due to the large interest in the culture for the system of crop rotation and the great demand for its derivatives, it is necessary to practice research to obtain a greater production of sunflower in the area of cultivation (Amorim et al., 2007). One of the possible ways to obtain greater production is by using region adapted hybrids and by increasing the arrangement of plants to obtain a larger number of plants with production capacity without losing quality and oil content (Leite et al., 2005). Several sunflower cultivars are used for oil production, silage, feeding birds and ornamentals. They are available in the market and the choice of the genetic material becomes a decisive factor, mainly because of the edaphicclimatic adaptation in the region, highlighting the importance of evaluating the genotypes in diferente locations (Oliveira et al., 2005).

Due to the great prospect of expansion throughout the country, research with agronomic characteristics of the crop (Castro and Farias, 2005) are determinant for a higher productivity. However, the sunflower productivity is not only related to environmental factors. The number of chapters per hectare and number of plants per area are the main factors of production (Rezende et al., 2003). Chapter yield of sunflower is lower because it only produces one chapter per plant, so plant density is critical to determine the number of plants per $\mathrm{ha}^{-1}$, which in turn, an inadequate density is influenced by edaphicclimatic conditions during the development of the culture which can cause great damage (Silva and Almeida, 1994). The use of sowing density in the implantation of the crop could influence the photoassimilation and conversion of photoassimilates, which in turn induces greater or lesser productivity. The use of a suitable number of plants per unit area and their absorption of solar rays is critical (Demetrio et al., 2008). In addition, the population density of plants directly influence the grain yield, since that any modification 
in plant arrangement will influence the final yield, e.g. very high density can cause bedding. Thus, the need for research to determine the best sowing density may influence the photoassimilation and conversion of photoassimilates, inducing higher productivity. The increase in sowing density may provide several benefits as mentioned; however, it is known that the larger the plant population, the greater the competition tendency for vital factors such as water and nutrients. However, as the sunflower produces only one chapter per plant, the higher number of plants $\mathrm{m}^{2}$ could compensate for this supposed competition, resulting in higher crop performance and better quality of the oil obtained by the cultivar (Silva, 2008). Therefore, the objective of this work was to evaluate two sunflower hybrids cultivated on different sowing densities, observing the influence on the agronomic characteristics of the production and the oil content of the crop.

\section{Results and Discussion}

According to the analysis of variance (Table 1), we observed a significant interaction between the cultivar $\times$ plant density, on the agronomic variables evaluated; Height of plants $(\mathrm{PH})$ and diameter of stem (SD). For the variables, number of leaves (NL), chapter thickness (TC) and chapter size (SC), there was a significant effect only in different cultivars. The averege values obtained for plant height $(\mathrm{PH})$ of the cultivars according to the different densities were adjusted to the quadratic model of the regression (Fig 2). It can be observed that the $\mathrm{PH}$ varied according to the densities, obtaining a higher value for the lower density of 30 thousand plants ha ${ }^{-1}$ $(217 \mathrm{~cm})$ and the smaller $\mathrm{PH}$ as a function of 40 thousand ha ${ }^{1}$ plants $(209 \mathrm{~cm})$ in the cultivate BRS324. There was an increase in height in the densities of 50 and 60 thousand plants $\mathrm{ha}^{-1}$, where it reached its minimum point in the density of 43,333 thousand plants with PH of $212.97 \mathrm{~cm}$, possibly due to the greater competition for luminosity, as opposed to the lower density, in which the highest luminosity allowed to express its maximum growth. A different effect was observed for cultivar M734. It can be observed that the PH decreased as the density increased. The maximum $\mathrm{PH}$ with size of $200.22 \mathrm{~cm}$ was observed in the density of 33,333 thousand plants. A probable reason is that the edaphicclimatic conditions at Toledo were favorable to cultivate; thus, expressing all its potency at lower densities and stabilizing its $\mathrm{PH}$ at higher densities up to 50 thousand $\mathrm{ha}^{-1}$ plants. Similar result was found by Rezende et al. (2003), in the State of Minas Gerais, tested adaptability of several cultivars at different densities and observed higher height on its lower density $\left(40,000 \mathrm{ha}^{-1}\right.$ plants). At the densities of 50 and 60 thousand plants $\mathrm{ha}^{-1}$, higher plant heights can occur with increased intraspecific competition due to greater competition for light (Silva et al., 1995). Results found in the experiment in Toledo is within the average cited by Castiglioni et al. (1994), where the height of the sunflower can vary from 50 to $400 \mathrm{~cm}$. In a similar work, it was observed that sunflower generally reached a height from 100 to $250 \mathrm{~cm}$ (Castiglioni et al., 1994). Faria et al. (2013) worked on sveral sunflower genotypes in the State of Mato Grosso in the 2011 harvest and observed that Toledo M734 (the same cultivar used in this experiment) did not fully expressed its growth point, with a mean of $148 \mathrm{~cm}$, which is lower than the other cultivars evaluated. The higher $\mathrm{PH}$ at lower densities is explained by the cultivar's late cycle and medium to high size (Ungaro,
2000). It can express any higher PH depend on edaphoclimatic conditions. For the stem diameter (SD) (Figure 3) of cultivar BRS324, which was submitted to different sowing densities, a decreasing quadratic effect could be observed, obtaining the highest diameter in the density of 30 thousand plants $(26 \mathrm{~mm})$, and the lowest diameters in the densities of 40, 50 and 60 thousand plants $\mathrm{ha}^{-1}$, reaching the minimum point when being submitted to the density of 56.250 thousand plants, with a diameter of $19.32 \mathrm{~mm}$. This possibly occurs due to the increase in plant density, in which they compete with each other for essential elements such as luminosity, affecting the height increase and reduction of stem diameter. The results of this variable can be based on studies conducted by Bezerra et al. (2014), which verified significant reductions in SD as a function of the increase of the seeding density of the sunflower in Fortaleza, which was lower than results found in the experiment. In cultivar M734, the mean values of stem diameter (SD) was adjusted in a quadratic model, where the SD at the density 45,000 plants $\mathrm{ha}^{-1}$ provided better behavior $(28.35 \mathrm{~mm})$, decreasing with increasing density of 50 and 60 thousand plants $\mathrm{ha}^{-1}$. This high variation in SD with the density change was possibly occurred due to the climate of the micro-region of the experiment, statistically different from the cultivar BRS324, which is produced and adapted to Paraná. The result found in the Toledo experiment was within the mean reported by Castiglioni et al. (1994), who observed averege of SD is between 15 and $90 \mathrm{~mm}$, well within the mean value. The results of the experiment were similar to those reported by Silva et al. (2003). (2009) in the city of Rio Verde (GO), where they obtained smaller SD means. Castro and Farias (2005) mentioned that stem diameter depends on genetic characteristics and is greatly influenced by environmental conditions, such as arrangement of plant population. This probably explains the interaction between cultivar $\times$ density in the SD found in the work.

\section{Effect isolated from cultivars}

Table 2 shows the analysis of agronomic characteristics. It can verify that for the variable number of leaves (NL), the cultivar BRS324 expressed a better behavior as a function of cultivar M734, with an average of 18.02 leaves per plant. Castiglioni et al. (1997) reported that the number of sunflower leaves can range from 20 and 40 leaves. The NL in this work is lower than those reported by Castiglioni et al. (1997). This variation may have occurred because of climatic influences affecting the leaf production during the formation phase between V1 and Vn as leaves play very important role directly linked to the photosynthetic rates and the growth and development of the plant in all its development stages (Taiz and Zeiger, 2009). Table 2 also shows the variable thickness of the chapter (TC) and chapter size (TC) in cultivar BRS324, which was statistically different from M734, obtaining 27.32 $\mathrm{mm}$ of SC and $21.99 \mathrm{~cm}$ for TC, respectively. The results obtained in the experiment corroborate with the results obtained by Leite et al. (2005), in which they mention that the sunflower can vary the SC of 5 to $30 \mathrm{~mm}$ and TC of 15 to 25 $\mathrm{cm}$. The results obtained in Toledo are superior to those reported by Silva et al. (2009), who tested three sunflower hybrids in the municipality of Rio Verde (GO), averaging $12.20 \mathrm{~cm}$ of TC, being below the average reported by Leite et al. (2005). Thus, our current experiment conducted in Toledo is consistent with the pattern cited by other authors. 
Table 1. Averages, overall mean, F values and coefficient of variation (CV), for Plant Height (PH), stem diameter (SD) number of leaves (NL), chapter thickness (TC) and chapter size (SC) in function of the different cultivars and densities used in the sowing of Sunflower in the western Paraná crop 2014/2015

\begin{tabular}{|c|c|c|c|c|c|}
\hline Sources of variation & $\mathrm{PH}$ & SD & $\mathrm{NL}$ & $\mathrm{TC}$ & $\mathrm{SC}$ \\
\hline & $(\mathrm{cm})$ & $(\mathrm{mm})$ & & $(\mathrm{mm})$ & $(\mathrm{cm})$ \\
\hline \multicolumn{6}{|c|}{ Overall average } \\
\hline & 210.31 & 25.22 & 17.87 & 25.92 & 20.85 \\
\hline \multicolumn{6}{|c|}{ F value } \\
\hline Cultivars & $10.042^{*}$ & $25.262^{*}$ & $7.657^{*}$ & $4.495^{*}$ & 30.116 \\
\hline Density & $5.500^{*}$ & $2.184^{\mathrm{ns}}$ & $1.793^{\mathrm{ns}}$ & $0.182^{\text {ns }}$ & $1.513^{\mathrm{ns}}$ \\
\hline Cultivars x Density & $5.586^{*}$ & $4.651^{*}$ & $1.447^{\mathrm{ns}}$ & $0.970^{\mathrm{ns}}$ & $0.114^{\mathrm{ns}}$ \\
\hline $\mathrm{CV}(\%)$ & 1.33 & 7.68 & 1,71 & 14.41 & 5.65 \\
\hline
\end{tabular}

ns: not significant at the $5 \%$ probability level by the $\mathrm{F}$ test; *: Significant at the $5 \%$ probability level by the $\mathrm{F}$ test. $\mathrm{CV}_{-}$Coefficient of variation.

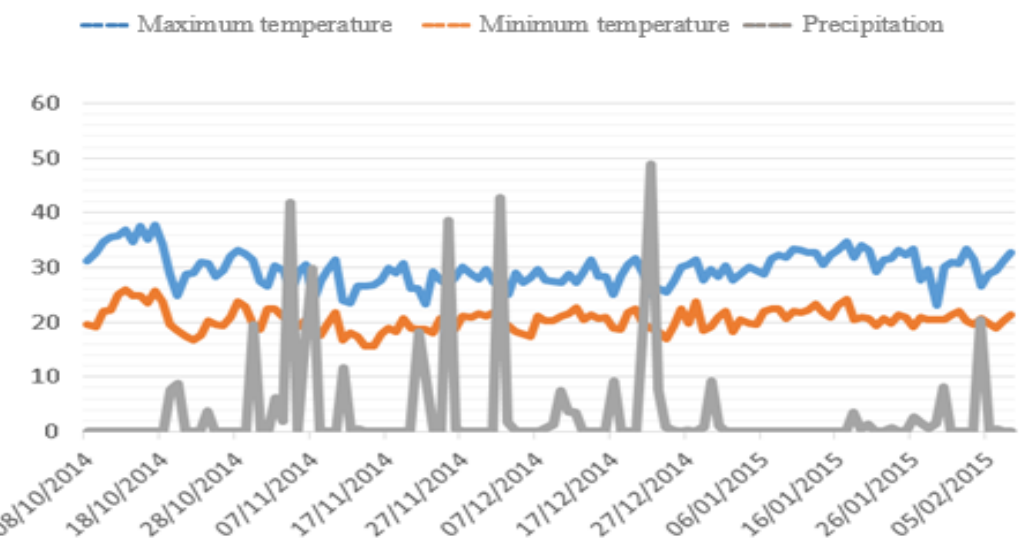

Fig 1. Demonstration of temperature $\left({ }^{\circ} \mathrm{C}\right)$, maximum and minimum data and rainfall in the experiment period.

Table 2. Average results according to the cultivars for leaf number (NL), chapter thickness (TC), size of the leaves (SC), according to the different cultivars used BRS324 and M734

\begin{tabular}{llll}
\hline Sources of variation & NL & TC & SC \\
\cline { 2 - 4 } Cultivars & & $(\mathrm{mm})$ & $(\mathrm{cm})$ \\
M734 & $17.72 \mathrm{~b}$ & $24.52 \mathrm{~b}$ & $19.71 \mathrm{~b}$ \\
BRS324 & $18.02 \mathrm{a}$ & $27.32 \mathrm{a}$ & $21.99 \mathrm{a}$ \\
& & & \\
\hline MSD & 0.2240 & 2.7465 & 0.8668 \\
\hline
\end{tabular}

Mean followed by the same lowercase letter, do not differ among themselves by the tukey test at $5 \%$ probability. MSD_ Minimum Significant difference

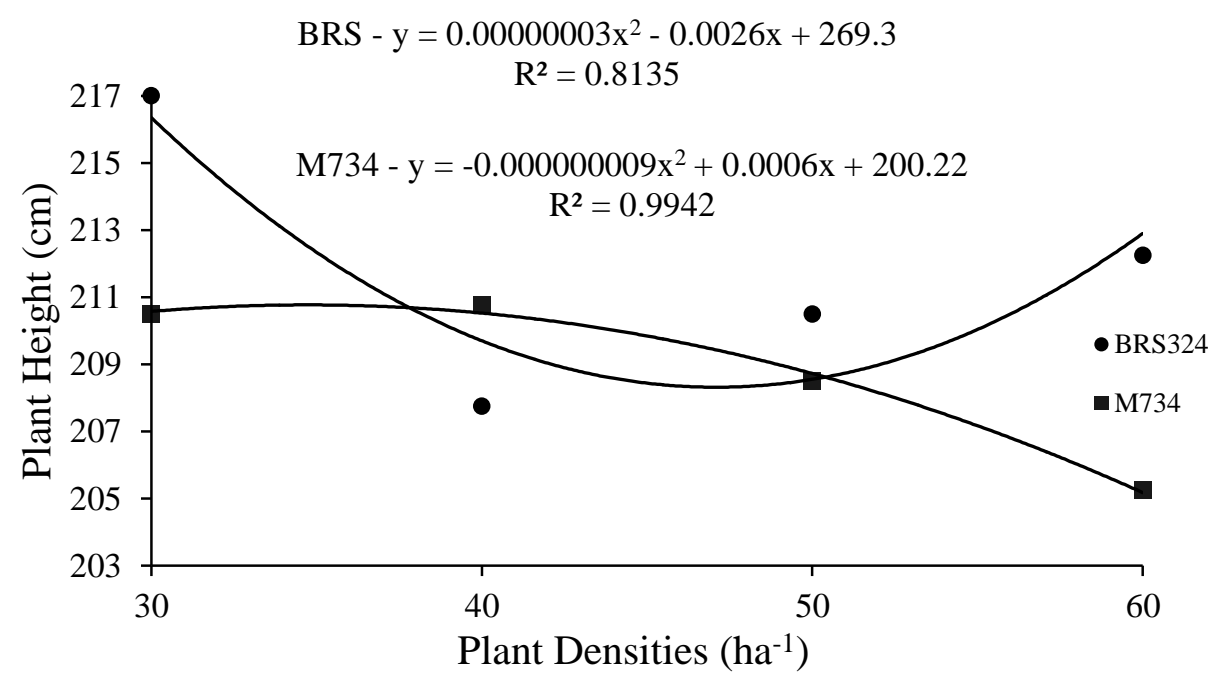

Fig 2. Plant height $(\mathrm{PH})$ in $\mathrm{cm}$ according to the different cultivars $\mathrm{x}$ seeding densities in the sunflower crop, cultivars BRS324 and M734. 
Table 3. Mean, general average, F values, coefficient of variation (CV), for mass of a thousand achenes (MTA), yield and oil content (OC) according to the different cultivars and densities used in the sowing of Sunflower in the western Paraná 2014/2015

\begin{tabular}{cccc}
\hline & MTA & Productivity & OC \\
\hline Sources of variation & $(\mathrm{g})$ & $\left(\mathrm{Kg} \mathrm{ha}^{-1}\right)$ & $(\%)$ \\
\hline & & Overall average & 36.61 \\
\hline Cultivars & 1113.47 & \\
Density & F value & $10.354^{*}$ \\
Cultivars x Density & 8.17 & $0.747^{\mathrm{ns}}$ & $0.266^{\mathrm{ns}}$ \\
\hline CV\% & $2.093^{\mathrm{ns}}$ & $0.660^{\mathrm{ns}}$ & $0.197^{\mathrm{ns}}$ \\
\hline
\end{tabular}

ns: not significant at the 5\% probability level by the $\mathrm{F}$ test; *: Significant at the 5\% probability level by the $\mathrm{F}$ test. $\mathrm{CV} \_$Coefficient of variation

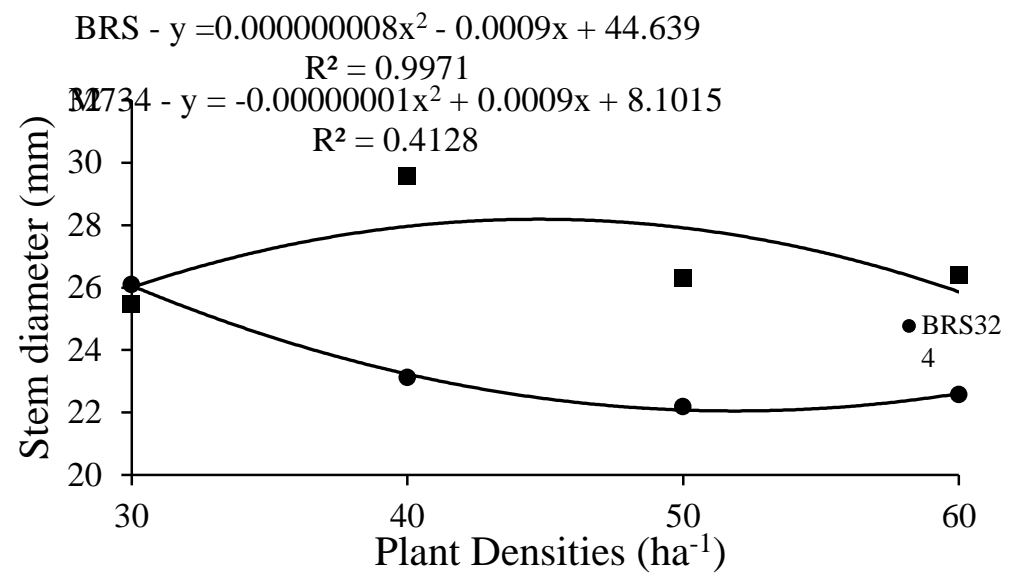

Fig 3. Stem diameter (SD) in mm according to the different cultivars $x$ seeding densities in the sunflower crop, cultivars BRS324 and M734.

Table 4. Average results according to cultivars for yield and Oil content (OC) according to the different cultivars used BRS324 and M734

\begin{tabular}{ccc}
\hline Sources of variation & Productivity of seeds & OC \\
\hline Cultivars & $\left(\mathrm{kg} \mathrm{ha}^{-1}\right)$ & $(\%)$ \\
M734 & $1191.50 \mathrm{a}$ & $34.81 \mathrm{~b}$ \\
BRS324 & $1035.43 \mathrm{a}$ & $38.41 \mathrm{a}$ \\
\hline MSD & 396.43 & 2.3283 \\
\hline
\end{tabular}

Mean followed by the same lowercase letter, do not differ among themselves by the tukey test at 5\% probability. MSD_ Minimum significant difference

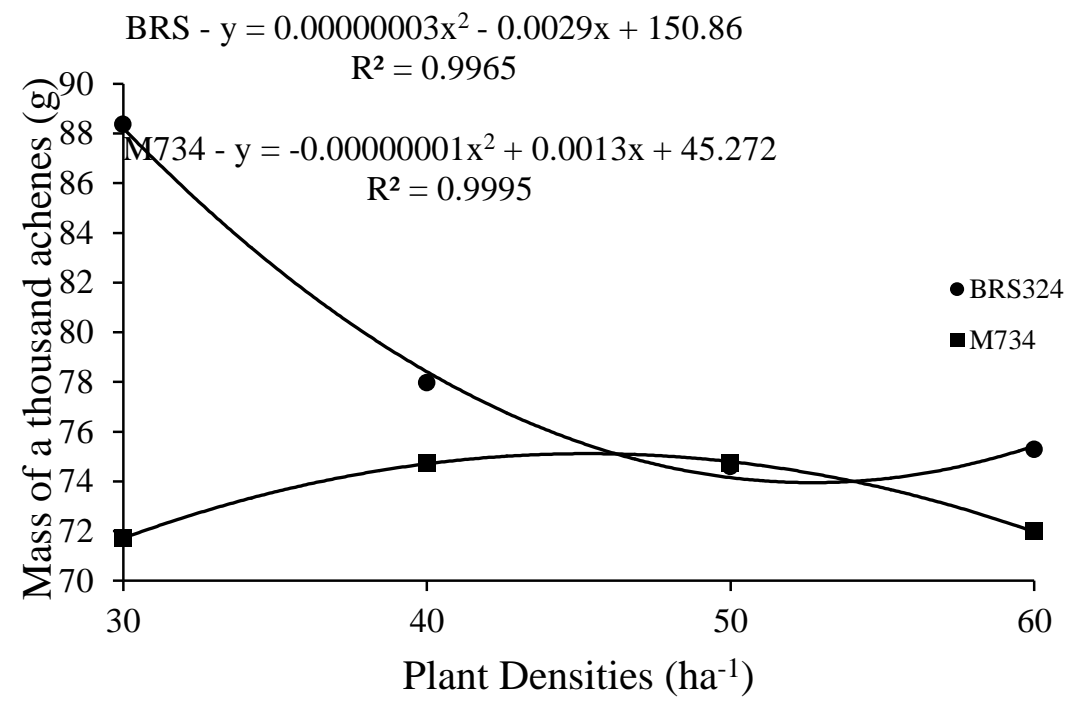

Fig 4. Mass of thousand achenes (MTA) in grams due to the different seeding densities in the cultivar BRS324 and M734. 


\section{Production and quality}

According to analysis of variance (Table 3), there was a significant effect for the interaction between cultivar and density only for the variable mass of a thousand achenes (MTA), whereas for the variables oil content (OC) there was a significant effect only in relation to the different cultivars. Analyzing two cultivars BRS324 and M734 in Fig 4, the differences between them are very evident due to the different seeding densities. The cultivar BRS324 achieved greater MTA, between 75 and $88 \mathrm{~g}$, reaching its minimum point in the density of 48,333 thousand plants, with MTA of $80.17 \mathrm{~g}$. The cultivar M734 reached the maximum point of MTA of $87.52 \mathrm{~g}$ in density of 65,000 plants. Even on their Maximum and minimun points, the MTA was still above those quoted by Embrapa (2013), in which it is reported that the mean mass of achenes of the BRS324 vary from 50 to 65 grams. It is still above of whats was measured by Castro et al. (1996), in which they observed that the MTA varies between 30 to 60 grams according to the cultivar tested. The results obtained in Toledo's experiment were also higher to those found by Santos et al. (2011). They implemented an experiment in 2010 at Recôncavo Baiano and reported higher MTA for the two cultivars compared to results obtained by Balbinot et al. (2009) in Toledo, which obtained an average of 52.1 grams of MTA. With these values, we can observe that the MTA had high yield for both cultivars, showing that the larger mass did not influence the sunflower oil content (Table 3).

The productivity (Table 3 ) did not show any significant difference between the cultivars evaluated and the means obtained in the experiment conducted in Toledo. They were below the average yield of sunflower according to Conab (2014), and the average productivity for the south of Brazil is estimated at 1,548 $\mathrm{kg} \mathrm{ha}^{-1}$. Santana et al. (2013), reported the production of achenes and sunflower oil in the semi-arid region (averaged 3,167 kg ha ${ }^{-1}$ ) for cultivation of BRS324 and $1,504 \mathrm{~kg} \mathrm{ha}^{-1}$ for M734, wich is higher than the results obtained by the experiment in Toledo. In related work on plant arrangement, Bezerra et al. (2014) reported lower productivity than the average production $\left(702.64 \mathrm{~kg} \mathrm{ha}^{-1}\right)$. They attributed such a low productivity as a function of environmental factors. The productivity of the experiment in Toledo was possibly affected by the drought period in January 2015 (Fig 1), due to the low availability of water in the flowering stage and filling of achenes. Another factor of low productivity is attributed to the attack of birds occurred in the R9 stage, shortly before harvest. According to Ungaro (2000), the birds attack the chapters during the stage of grain filling, causing partial or total destruction. In large crops the damage is diluted, but on smaller areas the damage is quite expressive. It can be observed in Table 4 that, even the cultivars that were exposed to a typical factor had similar productivity in other experiments. So, we can conclude that if the crop had not suffered drought and bird attack it could have expressed a higher productivity. For the variable oil content (OC), the cultivar BRS324 obtained a higher mean, $(38.41 \%)$, statistically different from M734. These results obtained in the experiment were below the mean quoted by Embrapa (2013), where it is reported that the OC of BRS324 can reach 45 to $49 \%$. Smiderle et al. (2005), reported that cultivars showed a OC of $37 \%-41 \%$, values that are within the range of 10 to $60 \%$ OC that the sunflower can express.

\section{Materials and Methods}

\section{Characterization of the experimental area}

The experiment was conducted in the experimental field of the Pontificial Catholic University of Paraná, under the geographical coordinates: latitude $24^{\circ} 43$ '42 "S, longitude $53^{\circ} 46^{\prime} 05^{\prime \prime} \mathrm{W}$ and altitude of $566 \mathrm{~m}$ located in the city of Toledo - PR. The experiment was conducted in a soil classified as Red Latosol Dystroferric (Embrapa, 2013). The climate of the region according to Köppen is the subtropical type, with rains well distributed during the year and hot summers (Cfa). The experiment was conducted at a no-tillage site with succession of crops (SEAB, 2010). The meteorological data were obtained from the station of the Pontifical Catholic University of Paraná. The precipitation in the experiment period was $416.2 \mathrm{~mm}$ from the sowing to the harvesting, being within the mean (Castro et al., 1996). The water requirement of the sunflower is 200 to $900 \mathrm{~mm}$ well distributed throughout the cycle, which result in yields close to the maximum.

\section{Treatments and experimental design}

The experiment employed was the randomized block design in a factorial scheme, $2 \times 4$ with four replications. Two cultivars were used, being BRS324 and M734 cultivated in four different densities; 30, 40, 50, 60 thousand plants ha $^{-1}$, totaling 32 plots. The cultivar BRS324 was developed by Embrapa, had a high productive potential in our grains, being able to reach 45 to $49 \%$ oil content in the achenes. It is an early variety with different characteritics for each productive systems of the main regions of the country, aggregating values in production (Embrapa, 2013). The cultivar M734 was developed by Dow AgroSciences which had a high productive potential with 35 to $43 \%$ oil content in the achenes. It is a variety of late cycle, medium to high size, and has good characteristics for different production systems.

\section{Experimental management}

Before the installation of the experiment, the soil sampling was performed in depth from 0 to $0.20 \mathrm{~m}$, with the aid of a Dutch type piercer for the characterization of chemical attributes and soil granulometric. According to the methodology of Raij et al. (2001), (17.1 - 4.34 - $34.76-0.34$ $\left.\mathrm{mg} \mathrm{dm}^{-3}\right), \mathrm{K}, \mathrm{Ca}, \mathrm{Mg}$, and $\mathrm{Pb}, \mathrm{Al}, \mathrm{H}+\mathrm{Al}, \mathrm{SB}, \mathrm{CTC}, \mathrm{H}+\mathrm{Al}$ $(0.2$ - $4.0-1.76-0.19-5.35-5.96-11.31$ cmolc dm - 3) Clay, Silt and Sand (52.7 - $78-17$ and 5\%). During the sowing, a seeder was used to only perform the marking of the lines and deposition of chemical fertilization, fertilizer FERTIPAR formulated NPK 08-20-20, in an amount of 400 $\mathrm{kg} \mathrm{ha}^{-1}$, deposited in the lateral sowing groove and below the seeds. At R1, a manure was manually handled in the amount of $40 \mathrm{~kg} \mathrm{ha}^{-1}$ of $\mathrm{N}$, as ammonium sulfate $(22 \% \mathrm{~N}$ and $24 \% \mathrm{~S})$. For the control of weeds, 30 days before the implantation of the crop was done the desiccation of the area using the herbicide glyphosate, in the dosage of $2.5 \mathrm{~kg} \mathrm{ha}^{-1}$. Seeding was performed after 20 days of desiccation. Throughout the development of the crop, the experiment was monitored in order to verify the emergence of sunflower and seedlings of unwanted plants. Manual weeding was performed to control the unwanted plants up to the first thirty days of the development of the culture. After this period, the sunflower crop had a rapid stem elongation and an increase in the 
number of leaves, which by itself suppressed the invasive plants quickly, diminishing the competition between cultivar and plants. The sowing was started on 08/10/2014 for cultivars BRS324 and M734 manually, depositing 3, 4, 5 and 6 seeds per linear meter, respectively, considering the germinative power of each cultivar, to maintain the desired plants quantity of approximately $30,40,50$ and 60 thousand plants per hectare $\left(\mathrm{pl} \mathrm{ha}^{-1}\right)$, to a depth of 3 to $5 \mathrm{~cm}$. The length of each plot was determined before sowing, with spacing of $0.7 \mathrm{~m}$ and each line of $5.0 \mathrm{~m}$ in length, totaling 5 lines for each plot. For the sowing, a measuring tape was used to measure the length of the line. The cutting wood pieces were placed to determine the spacings between seeds for each density of $33.33 \mathrm{~cm}, 25 \mathrm{~cm}, 20 \mathrm{~cm}$ and $16.67 \mathrm{~cm}$, respectively. To cover the seeds we used a hoe, maintaining

the desired depth. For pest control, weekly monitoring of the area was carried out, observing the attack sites, that really justified its control according to the level of economic damage. The insecticide application was made if required. A large number of sunflower caterpillars (Chlosyine lacinia saundersii) were observed at the R7 stage, causing defoliation. For the control, the insecticide Profenofós + Lufenuron was applied at the dose of $300 \mathrm{~mL} \mathrm{ha}^{-1}$ as released in Paraná, with a Yamaho FT16 (16 L) costal electric pulverizer.

Harvesting was done manually in the useful area of each plot $\left(6.3 \mathrm{~m}^{2}\right)$, using a pruning shears for gardening, where the chapters of each plot were cut. It was removed and packed in plastic bags and then hand-drilled.

\section{Evaluations}

In order to carry out the evaluations, the first line of each side of the plot was disregarded. Thus, we evaluated only the three middle lines and excluded $1.0 \mathrm{~m}$ from each end and collected the remaining $3.0 \mathrm{~m}$ linear chapters of each plot line totaling $6.3 \mathrm{~m}^{2}$. Ten plants were randomly selected as following: number of leaves per count during flowering (5.1); Height of plants with the aid of a measuring tape measuring from the base of the stem to the apex of the plant in the full bloom phase (R5.5); Diameter of the stem, in millimeters $(\mathrm{mm})$, with the aid of a manual stainless steel pachymeter (Régulus mark), measured at a height of $5 \mathrm{~cm}$ from the ground at the full flowering point (R5.5); Thickness of the stem, measured in the same way as the stem diameter variable, but in the physiological maturation phase (R9); Size of a chapter in centimeters $(\mathrm{cm})$, with the aid of a measuring tape, measuring from one end of the chapter to the physiological maturation point (R9). The mass evaluations of thousand achenes, yield and oil content were performed after the harvest. The mass of thousand achenes was determined by counting and 500 achenes and after conversion. Productivity was determined by harvesting the area of $6.3 \mathrm{~m}^{2}$ per plot and then converting the values to $\mathrm{kg} \mathrm{ha}^{-1}$. The evaluation of oil content, in percentage $(\%)$, was made using the continuous Goldfish method. Samples of sunflower seeds were chrushed and $2 \mathrm{~g}$ weighed and added in cartridge or envelopes with adapted paper filter to the Golsdfish apparatus at $60^{\circ} \mathrm{C}$ for a period of 4 hours. After this period a sample was taken and placed in an ether collector at $105^{\circ} \mathrm{C}$ for 30 minutes. Subsequently, the samples were removed and placed in a desiccator to cool for 20 minutes. Afterwards they were weighed and their weight were recorded. The calculation was then carried out to obtain the percentage of oil by means of the formula below.

\section{$\mathrm{R}=\underline{\text { Final balloon weight }- \text { Inicial weight }} \times 100$ Sample weight}

Alves et al. (2010)

\section{Statistical analysis}

After data collection, they were submitted to analysis of variance by the $F$ test. The means of the cultivars were compared by the Tukey test and the population densities subjected to the regression analysis at a significance level of $5 \%$ of probability using the SISVAR software (Ferreira, 2011).

\section{Conclusion}

The cultivar BRS324 presented the best agronomic characteristics. Even though it was not significantly higher in productivity, produced a better yield of oil content. Among the production characteristics, plant height and stem diameter for the cultivars tested showed the opposite behavior, possibly due to adaptation in the western region of Paraná. The mass of 1000 achenes was descending according to the increase in population density for cultivar BRS324.

\section{References}

Alves A, Amorim J, Jane P, Barreto V (2010) Experimental organic chemistry II, Federal University of Amazonas, 1-8.

Amorim EP, Ramos NP, Ungaro MRG, Kiih TAM (2007) Divergência genética em genótipos de girassol. Ciênc Agrotec. 31:1637-1644.

Balbinot Junior AA, Backes RL, Souza AM (2009) Desempenho de Cultivares de Girassol em três Épocas de Semeadura no Planalto Norte Catarinense. Scientia Agraria. 10:127-133.

Bezerra FTC, Dutra AS, Bezerra MAF, Oliveira Filho AF de, Lima Barros G de (2014) Comportamento vegetativo e produtividade de girassol em função do arranjo espacial das plantas. Rer Ciên Agron. 45:335-343.

Castiglioni VBR, Balla, A, Castro, CD, Silveira, JD (1994) Fases de desenvolvimento da planta de girassol. EmbrapaCNPSo. Documentos.

Castiglioli VBR, Balla A, Castro C de, Silveira JM (1997) Fases de desenvolvimento da planta de girassol. Londrina: Embrapa-CNPSo, 24p. (Embrapa-CNPSo. Documento 59).

Castro, C, Castiglioni VBR, Balla A, Leite Rmvbc KD, Mello HC, Guedes LC A, Farias, JRB (1996) A cultura do girassol. Embrapa-CNPSo. p.2.

Castro C de, Farias JRB (2005) Ecofisiologia do girassol. In: Leite RMVBC.; Brighenti A. M, Castro C de. Girassol no Brasil. Embrapa Soja, p.163-218.

Companhia Nacional de Abastecimento - CONAB (2014) Girassol. 37 p.

Demétrio CS, Fornasieri FD, Cazetta JO, Cazetta DA (2008) Desempenho de híbridos de milho submetidos a diferentes espaçamentos e densidades populacionais. Pesq Agrop Bras. 43:1691-1697.

Empresa Brasileira de Pesquisa Agropecuária - Cultivar BRS324 EMBRAPA, 2013. Disponível em: http://www.infoteca.cnptia.embrapa.br/infoteca/bitstream/d oc/980648/1/folderBRS324copy.pdf. Acesso em 20 ago. 2015.

Faria DA de, Ferrari M, Ramos J, Carvalho C, Campos DDS, Borba Filho AB (2013) Avaliação do desempenho agronômico de genótipos de girassol no município de Campo Verde-MT, na safra de 2012. In Embrapa Soja- 
Artigo em anais de congresso. In: Reunião Nacional de Pesquisa de Girassol, 20; SIMPÓSIO NACIONAL SOBRE A CULTURA DO GIRASSOL, 8., 2013, Cuiabá. Anais. Embrapa.

Ferreira DF (2011) Sisvar: um programa para analises e ensino de estatística. Rev. Cient. Symposium, 6:36-41.

Leite RMVBC, Brighenti AM., Castro C de (2005) Girassol no Brasil. Embrapa Soja, 641p.

Oliveira MF de, Castiglioni VBR, Carvalho GP de (2005) Girassol no Brasil. Embrapa Soja, 269-294.

Raij B van, Andrade JC. de, Cantarella H, Quaggio JA (2001) Análise química para Avaliação da Fertilidade de Solos Tropicais. Campinas: Instituto Agronômico de Campinas. $285 \mathrm{p}$.

Rezende A, Evangelista A, Siqueira G, Barcelos A, Rocha G, Santos R (2003) Efeito da densidade de semeadura sobre a produtividade e composição bromatológica de silagens de girassol (Helianthus annuus L.). Ciên Agrotec. ed esp:1672-1678.

Santana PR De, Silva WP, Dourado SB, Souza MS de, Cruz F de A, Mendes MF, Leite VM (2013) Produção de Grão e Óleo de Girassol no Semiárido, Semeado Fora da Época de Zoneamento Agroclimático. Anais, XX Reunião Nacional de Pesquisa de Girassol - VIII Simpósio Nacional sobre a Cultura do Girassol.

Santos GA, Zonetti P da C (2009) Influência da temperatura na germinação e desenvolvimento do girassol (Helianthus annuus L.). Inic Cient Cesumar. 11:23-27.

Santos AMPB dos, Machado G da S, Peixoto CP, Cruz TV da, Santos JM da S dos (2011) Desempenho de híbridos de girassol em sistema plantio direto no recôncavo baiano. Enc Biosfera. 7:323 - 330 .

Seab. Secretária da Agricultura e abastecimento do Paraná, 2010.

<http://www.agricultura.pr.gov.br/arquivos/File/deral/Progno sticos/agrometeorologia_2010_11.pdf $>$. Acesso em: 11 nov. 2015.
Silva PRF, Almeida ML (1994) Resposta de girassol à densidade em duas épocas de semeadura e dois níveis de adubação. II - Características de planta associadas à colheita. Pesq Agrop Bras. 29:1365-1371.

Silva PRF, Rizzardi MA, Trezzi MM, Almeida ML de (1995) Densidade e arranjo de plantas em girassol. Pesq Agrop Bras. 30:797-810.

Silva AG, Morães EB de, Pires R, Carvalho CGP de, Oliveira ACB, Teixeira IR (2009) Efeitos do espaçamento entre linhas nos caracteres agronômicos de três híbridos de girassol cultivados na safrinha. Pesq Agrop Trop. 39:105110

Silva MR (2008) Girassol beneficia Culturas Subsequentes. Rev. Campo e Negócios, 1:74-75.

Smiderle OJ, Mourão Jr M, Gianluppi D (2005) Avaliação de cultivares de girassol em savana de Roraima. Acta amazônica, 35:331-336.

Ungaro MRG (2000) Cultivo e processamento de girassol. Tecnologia e Treinamento agropecuário. 4:1-43.

Taiz L, Zeiger E (2009) Fisiologia Vegetal. 4. ed. Porto Alegre: ARTMED. 848 p. 